\title{
Yoksulluğun Gündelik Hayat Üzerinden Analiz Edilmesinde Anahtar Bir Kavram: Hayatta Kalma Stratejileri Üzerine Yapısal Bir Çalışma
}

\author{
Hande ŞAHIN*
}

$\ddot{O} Z$

Hayatta kalma stratejisi kavramı, özellikle 1980'lerin sonu ile birlikte sosyal bilimler literatürü içinde oldukça popüler hale gelmiştir. Bu durum, dünyada yaşanılan birçok gelişme ile yakından ilişkilidir. Yapısal uyum süreçleri ve neo liberal politikalar, tüm dünya ekonomilerini doğrudan etkilemiş, sosyal devlet olma anlayışından giderek uzaklaşılmıştır. Enflasyon oranları artmış ve yoksulluk ise derinleşmiştir. Bu süreçte sosyal sinıfları giderek korumasız kalmışlardır. Tüm bu gelişmeler, karşısında hane halkı tüm kaynaklarını hayatta kalmak için kullanmıştır. Kavramin, yoksulluk, dezavantajlı gruplar gibi birçok kavramla ile birlikte anılma sebebi budur. Özellikle azgelişmiş ülkeler ve Doğu'daki Post Komünist ülkeler ve merkez ülkelerin kendi alt sinıfları bu süreçten en olumsuz ekilenler olmuştur. Bu yüzden hayatta kalma stratejileri ile ilgili literatür özellikle bu ülkelerin teorisyenlerince geliştirilmiştir. Kavram, bu ülkelerin ve özellikle de yoksulların bu süreçten nasıl etkilendiğini anlamak için de kullanılmıştır. Kavramın, yoksulluk literatürü üzerinden şekillenmesi, geçinme stratejileri, mücadele stratejileri, hane halkı stratejileri gibi birçok kavramla iç içe geçerek kullanılmasını beraberinde getirmiştir. Türkiye'de bu alanda verilmiş çalışmalarda da benzer bir durum vardır. Tüm bu kavramlar çoğunlukla birbirinin yerine ve yoksullukla mücadele etmede kullanılan stratejiler anlamında kullanılmaktadır. Hazırlanmış olan bu çalışmanın amacı, kavramın içeriğini incelemek, kavramla ilgili literatürün yapısal bir analizini yapmaktır. Bu doğrultuda çalışmanın yöntem olarak öncelikle Türkçe ve yabancı literatürü taramıştır. Kavramın literatür içinde nasıl şekillendiğiniele almıştır. Sonrasında bu alanda yapılmış çalışmalar irdelenmiştir. Çalı̧̧ma sonucunda kavramın, özellikle yoksullak mücedele sürecinde başvurulan bir kavram olduğu görüşmüştür. Yoksulluk temelinde yapılan çalışmalar göstermektedir ki hayatta kalma stratejileri giderek daha bireysel ve hanesel bir boyut kazanmaktadir. gündelik hayat

Anahtar Kelimeler:Hayatta kalma stratejileri, yoksulluk, hane halkı stratejileri, Türkiye, Jel Sinfilandirmast: P36, P26, Z13

\section{A Key Concept in Analyzing Poverty Through Everyday Life: A Structural Study on Survival Strategies}

\section{ABSTRACT}

The concept of survival strategies has become very popular in the social science literature, especially since the end of the 1980s. This is closely related to many of developments experienced in the world. Structural adjustment processes and neo-liberal policies have directly affected economies around the world, causing them to move away from the understanding of a social state. Inflation rates have increased and poverty has deepened. In this process, the social classes have become increasingly unprotected. In the face of all these developments, all

\footnotetext{
* Doç. Dr, Manisa Celal Bayar Üniversitesi İ.İ.B.F. Çalışma Ekonomisi ve Endüstri İlişkileri Bölümü Öğretim Üyesi, hande.sahin@cbu.edu.tr
} 
households used their resources to survive. This is the reason why the concept is understood with many concepts such as poverty and disadvantaged groups. Especially underdeveloped countries and Post Communist countries in the East and their subclasses of central countries are the most adversely affected from the process. Therefore, the literature on survival strategies has been developed especially by the theorists of these countries. The concept has also been used to understand how these countries, and especially the poor, are affected by this process. Structuring the concept through the literature of poverty has brought together the use of many concepts such as livelihood strategies, struggle strategies, and household strategies. There is a similar situation in the studies given in this field in Turkey. All these concepts are often used in place of each other and in the sense of strategies used to struggle against poverty. The aim of this work is to examine the concept and to make a structural analysis of the literature on the concept. As a method of the work in this direction, primarily Turkish and foreign literature were searched. How the concept was shaped in the literature was questioned. As a result of the study, it is seen that the survival strategy is a concept applied especially in the process of poverty struggle. Studies based on poverty show that survival strategies are becoming increasingly indiviadual or household-based.

Keywords: Survival strategies, poverty, household strategies, Turkey, Daily life

Jel Classification: P36, P26, Z13

\section{GíRIŞ}

Gündelik olan tüm toplumlarda insanın soyunu devam ettirmek için geliştirdiği yeme içme, barınma, üreme, güvenlik gibi insani gereksinimleri kapsar. Dünyanın her yerinde bulunan insanlar kendileri için varlıklarını sürdürmenin yollarını keşfederler ( Şahin ve Balta, 2001: 136). Bu keşfetme süreci mekanik olarak her gün yeniden yapılanır. Toplumsal koşullara bağlı olarak yeniden yeniden şekillenir. Hayatta kalma stratejileri gündelik olanın mekanik olan yanıdır. Bu açıdan gündelik olanın anlaşılmasında hayati bir öneme sahiptir. Gündelik olan ise makro olanın çözümlenmesinde önemli ipuçlarını içinde barındırır, yapıya ait kara kutu işlevi üstlenir. Bu yüzden yapı, gündelik hayat ve hayatta kalma stratejileri iç içe geçmiş matruşkalar gibidir. Birinin anlaşılmasında öteki yol gösterici olmaktadır. Çalışma hayatta kalma stratejileri kavramına böyle bir kabul üzerine inşa etmeyi hedeflemektedir.

Kavram, ontolojik olarak tüm güçsüzlüklerine rağmen, aktörlerin kaderlerini, hayatlarını belirleyebileceği beklentisine dayanır. Bekalarını sağlamak adına kendi tarzlarında etkin olduğunu kabul eder. Yoksulların, hayatta kalma için kendiliğinden örgütlülüğünü, rızkın üretilmesi için merkezi bir unsur olarak hane halkı kurumunu, güven karş1l1kl111k, iradecilik ve her türlü toplumsal gücün varlığını içine alır (Bayat, 2008: 36). Hayatta kalma stratejisi kavramı yoksulluk, göç, gündelik hayat, dezavantajlı gruplar gibi birçok kavramla ile ilişkilendirilerek özellikle bu kavramlara ait literatürler içinde önemli bir yere sahiptir.

Kavramın, bu kavramlarla ilişkilendirilerek ele alınmasının birçok farklı nedeni vardır. Bu durum, genel olarak 1980 sonrası tüm dünyada yaşanılan neo liberal dönüşümün farklı şekillerde tezahür etmesinin sosyal bilimler literatürüne yansıması olarak değerlendirilebilir. Ancak bu noktada önemle belirtilmesi gereken husus, kavramın sosyal bilimler literatüründen özellikle yoksulluk kavramı ile birlikte anılmasına karşın, Amis (1997: 97)'in de belirttiği üzere 
insanın var olma çabasına bağlı olarak çok eskilere kadar dayanmasıdır. Ancak II.Dünya Savaşı sonrasında ulus devletleşme sürecinde toplumsal refah ve sosyal devlet anlayışları ile birlikte daha makro bir bakış açısının parçası olmuştur. 1980 sonrasına gelindiğinde ise süreç tam tersi yönde işlemiş, yaşanılan neo liberal dönüşüme bağlı olarak devletin sosyal devlet olma işlevini giderek kaybetmesi ve diğer tüm gelişmelere paralel olarak, birey ve hane bazlı bir düzleme taşınmıştır. Bireysel kurtuluş, çözülen kollektiviteler karşısında bir çıkış yolu olarak görülmüştür. Sosyal bilimler literatürü odağinı makrodan mikroya yapıdan aktöre kaydırmış, modernite ve büyük anlatıların sınıllılıkları daha mikro anlatılar ve aktör odaklı teorilerle aşılmaya çalışılmıştır. Litaratürde yıllardır hakim olan yapısalcılık ve Marksiszm ise tüm bu dönüşümleri açıklamada yaşadığı sınırlılıklar ve gündelik olanı açıklamada yetersiz kalması bakımından eleştirilmiş, alanda yeni arayışlar baş göstermiştir. Hayatta kalma stratejileri, bu yeni arayışın gündelik hayat tartışmaları içinde bir kolu oluşturur. Kavram özellikle, derinleşen yoksulluk, kent yoksulluğu, işgücü piyasalarının enformelleşmesi gibi toplumsal sorunlarla baş edebilmede bir çözüm arayışının ürünüdür. Tüm bu sorunların ağırlığ karşısında aktörün de var olabileceğini direnebileceğini ortaya koymak adına geliştirilmiştir. Ancak buna rağmen ciddi anlam karmaşalarına ve bazen de yapının ikinci planda bırakılmasına sebep olmuştur. Kavram böylesi bir çabanın ürünü olduğundan dolayı, çoğu zaman mücadele stratejisi, geçinme stratejisi, hane halkı stratejisi gibi kavramlarla iç içe geçerek çoğu zamanda bu kavramların yerine kullanılarak literatürde yerini almıştır.

Strateji kavramı, Latin Amerika ve Afrika'da kent yoksullarının gündelik ekonomik faaliyetlerini analiz etmeyi, formel sektör kadar enformel sektörün de önemli olduğunu vurgulamayı amaçlayan hane halkı stratejilerine odaklanan çalışmalardan doğmuştur. 1980'lerin sonlarına doğru İngiltere'de Sheppey projesi olarak değerlendirilecek projeyi de kapsayacak şekilde işsizlik ve ekonomik değişimin etkilerinin neler olduğunu anlama biçimlerini ele alış biçimi olarak kullanılmıştır. (Wallace, 2002:275-6). Yapı yerine aktörü, birey yerine haneyi, formel yerine enformel olanı araştırma birimi olarak kabul eden bu çalışmalar, aslında sosyolojide o zaman kadar hakim olan paradigmaya bir karşı çıkıştır ve birçok tartışmayı da beraberinde getirmiştir. Buna rağmen kavram, Wallace (2002:276)'ın da belirttiği üzere Merkez Avrupa ve Doğu'daki Post Komünist ülkelerde yeniden yapılanma ve post Fordizmin aile ve iş üzerindeki etkisini konu alan çalışmalarda bir canlılığa sebep olmuştur.

Kavramın özellikle 1980'lerle beraber etkin olmasının bazı konjoktürel nedenleri bulunmaktadır. Bunların en başında 1980'lerin sonu ile birlikte Komünist toplumların ekonomilerinin piyasa kapitalizmi ile bozulmasıyla, derin bir enflasyon krizi ve yoksullaşma süreci yaşamalarıdır. Bu süreçte haneler, tüm kaynaklarını hayatta kalmak için kullandılar. Stratejileri kavramı değişen koşullar karşısında "neler olduğunu" anlamının bir yolu olarak görüşmüştür. İstatistiksel verilerin de az olduğu bu süreçte, sadece gelir, sosyo ekonomik 
durumların ve statülerin açıklanmasına yetmez hale gelmiştir. Hem sosyal yapıyı hem de kimlerin avantajlı kimlerin dezavantajlı konuma geldiğini anlamak için hane halkı temelli yaklaşımlar kullanılmıştır. Örneğin Rose ve Haerpfer (1992), çalışmalarında on ülkeden elde ettikleri ile geniş veri setleri oluşturarak haneleri marjinal, savunmasız, girişimci, savunmacı gibi kategorilere yerleştirmişlerdir (Wallace, 2002:28). Benzer bir çalışmayı Piirainen (1997) yapmıştır. Piirainen, St Petersburg'daki hanelerin kullandığı stratejilerden yola çıkarak onların gelecekteki toplumsal statülerinin neler olacağı yönünde kategoriler oluşturmuştur.

Hayatta kalma stratejilerinin, literatür içinde popülerlik kazanmasının bir diğer önemli nedeni de post fordizmdir. Post fordizm, tüm dünyada iş ve aileye dair birçok temel şeyin değişmesine neden olmuştur. İş ve aile modelleri, daha esnek bir istihdam modeli ve daha parçalı yaşam öyküleri, enformelleşme, esnekleşme üzerine yeniden yapılanmıştır. Kadınlar, derinleşen yoksulluk karşısında daha çok işgücü piyasasında yerlerini almıştır. II. Dünya Savaşı sonrası, ulus devletleşme süreci sosyal refah devletinin en etkin olduğu dönem olmuş, ancak devletin bu temel özelliği 1980 sonrası neo liberal politikalarla tarafindan terk edilmiştir. Bir önceki dönemde devletin güvencesi altında olan tüm sınıflar yeni gelişmeler karşısında savunmasız kalmışlardır. Her tür kollektivitenin çözüldüğ̈̈ süreçte hayatta kalmak bireysel ve hanesel çabalara kalmıştır. Bu durum, bir zorunluk bir çıkış gibi gösterilmiştir. Güvenceli ve sürekli işlerden mahrum kalanlar veya bu işlere sahip olsa bile derinleşen yoksulluk karşında elde ettiği gelir ile geçinemeyen herkes için bu tarz stratejiler, vazgeçilmez gösterilmiştir. Süreç, kuşkusuz ki gelişmekte olan çevre ülkeler ve merkez ülkelerin kendi çevre konumundaki dezavantajlı grupları için çok daha sancılı olmuştur. Bu açıdan toprak istilasından, işportacılığa en marjinal stratejilerin, bu gruplar içinde çıkması oldukça anlamlıdır.

Hazırlanmış olan bu çalışmanın temel amacı hayatta kalma stratejileri kavramını incelemek ve kavrama ait literatürün bir analizini yapmaktır. Çalışmanın amacı doğrultusunda aşağıdaki sorulara cevap aranmaktadır:

1) Kavramın konjoktürel olarak ortaya çıkışı ve sosyal bilimler literatürü içinde ne şekilde kendine yer bulmaktadır?

2) Kavram, dünyadaki hangi gelişmelerden etkilenerek şekillenmektedir?

3) Kavramın, metodolojik ve ontolojik olarak içinde barındırdığı avantajlar ve temel handikaplar nelerdir?

4) Tüm bu tartışmaların Türkiye'deki literatüre ve çalışmalara nasıl yansimaktadir?

Çalışmanın amacı doğrultusunda cevaplanması planlanan soruların özellikle ilk üçü hayatta kalma stratejileri ile ilgili literatür adlı ilk bölümde makrodan mikroya doğru ilerleyen yapısal bir analizle ele alınacaktır. Tüm bu tartışmaların Türkiye özeline yansımaları ise Hayatta Kalma Stratejisi Kavramı ve Kavram Üzerine İnşa Edilmiş Türkiye'deki Alan Araştırması Örnekleri adlı 
ikinci bölümde literatür ve alan araştırmalardan seçilen örnekler üzerinden tartışlacaktır.

\section{Hayatta kalma stratejileri ile ilgili literatür}

Hayatta kalma stratejilerinin literatür içinde yerleşmesinde sosyal bilimlerdeki bazı akımların etkisi büyük olmuştur. Gündelik hayat tartışmaları, Amerikan mikro sosyolojisi, Latin Amerika temelli yoksulluk çalışmaları, fenomonoloji teorileri, post yapisalc1lik ve post Marksizm hayatta kalma stratejilerine ait literatürü şekillendirmiştir.

Kavram, ilk başlarda Redclift (1986), Pile (1991), Portes (1994) gibi teorisyenlerce göçmenler, tarım işçileri, köylüler gibi dezavantajlı sosyal grupların başa çıkma ve hayatta kalma stratejileri için kullanılmıştır. Pahl ve Gershuny (1979) kavramı, tüm hanelere uygulayarak literatüre bu yönde bir katk1 sağlamışlardır. Hayatta kalma stratejisi, aktöre ve onun dönüştürücü gücüne odaklanmıştır. Kavram, aynı zamanda stratejilerin sadece çevre tarafından şekillenmediğini aynı zamanda çevreyi de şekillendirdiğine vurgu yapmaktadır. Böylece işin, Marksist literatürdeki geleneksel tanımının dışına da çıkılmış, enformel ekonomi ve domestik iş gibi kavramlar, literatüre dahil edilmiştir. İş (Morris,1997), sosyal ilişkiler içine yerleşmiş, anlamlı her tür aktivite olarak kabul edilmeye başlanmıştır.

Pahl (1988:253)'e göre bu durum, sosyal bilimler literatüründe uzun y1llar hâkim olan "var olan her şeyin kapitalizm gibi soyut ve dışsal güçlerin ürünü" olduğu anlayışından bir kopuştur. Crow (1989) gibi teorisyenler strateji kavramını oyun teorisi üzerinden analiz eder. Böylece rasyonellik ve aktif seçimlere vurgu yapmış olurlar. Bu durum, sosyoloji literatürünün kendi içindeki dönüşümünden bağımsız gelişmemiş̦tir. Aynı yıllar literatürün, aktörle ile yapıyı birleştirme çabalarının yoğun olduğu bir dönemdir.

Sosyolojide hâkimiyetini uzun yıllar korumuş olan yapısalcılık ve Marksist anlayiş, Giddens (1984), Long (2001) Sewell (1992) gibi birçok teorisyen tarafından eleştirilmiştir. Bu teorisyenlerin birçoğu, aktör ve yap1 arasında dengeli bir ilişki kurmak istemiştir. Bir taraftan aktörü pasif /edilgen konumundan kurtarmak istemişler öte taraftan da toplumu salt bireylerin toplamı gibi gören anlayışın hatalarına düşmekten kaçınmışlardır.

Giddens (1984:25-6) yapıyı, aktörlerin eylemleri tekrar tekrar yapılandırdıkları bir düzlem olarak kabul eder. Bu anlamda yapı bu eylemlerin hem aracı hem de sonucudur. Sadece toplumsal ilişkileri ve toplumsal olanı şekillendirmez aynı zamanda bunlar tarafından yeniden üretilip şekillenir. Bireyleri, kısıtlamak yerine onlara eylemleri için olanaklar sunar. Bu eylemler, farkında veya farkında olmadan gerçekleşebilir. Ancak bireyler, tüm bu eylemlerinin etkileri açısından farkındalık sahibidirler. Aktörlerin eylemleri belirli sınırlılıklar içinde gelişse de mutlaka özgür bir hareket alanına sahiptir. $\mathrm{Bu}$ durum, hayatta kalma stratejilerini rasyonel seçimlere dayandıran birçok teori ile paralellik içindedir. Hayatta kalma stratejileri ile ilgili teorilerin sosyolojideki bu bakış açısından beslendiği açıktır. Aynı şekilde Giddens ile 
benzer noktalarda duran Long ve Sewell de aktörün rasyonelliği ve seçimler yapabilirliğine vurgu yaparlar. Sewell (1992:20), aktör olmay1, toplumsal ilişkiler üzerinde kontrol sahibi olma olarak görür ve aktörün dönüştürme yetisine vurgu yapar. Long (2001: 16) da aktörün en zor durumlarda bile mevcut koşullara başa çıkabileceğine inanır. Bu teorisyenlerin aktör ve yapıyı ele alış biçimleri, hane halkı stratejilerinde ve yoksulluk gibi toplumsal sorunlar karşısında aktörün etkinliğini açıklayabilmede yol gösterici olmuştur.

Günümüzde hayatta kalma stratejileri ile ilgili literatür incelendiğinde iki ana eğilimin varlığından bahsedilebilir. Literatürün büyük bir kısmını, Michel De Certau, Henri Lefevbre gibi teorisyenlerin yer aldığı gündelik hayat pratikleri odaklı çalışmalar oluşturur. Yeme içme alışkanlıkları, boş zaman faaliyetleri gibi kültürel olana odaklanan bu çalışmalar, sınıfsal çözümlemelerden çok pratik olanı kültürel bir bakışla ele almaya odaklanırlar. Örneğin De Certau, "gündelik hayatı" olanla idare etmek, koşullara bağlı olsalar da sınırları aşan taktikler üzerinden okur. Tüm taktikleri, zayıf olanın sanatı olarak görür (De Certau,2009: 114). Lefevbre (2010) içinse gündelik hayat manevralar alanıdır. Gündelik hayatın diyalektik yapısı, dönüştürücü bir takım imkânları içinde barındırır. Lefebvre için bu yüzden gündelik hayat önemlidir. Yoksulluk da dâhil olmak üzere başa çıkılması gereken her türlü sosyal problemin çözüm alanıdır. Şahin ve Balta (2001: 186)'a göre insan belirli bir eylemi gerçekleştirirken bu eylemleri düşünceleriyle, duygularıyla sınayan, bilgi biriktiren ve değerlendiren bir varlık olduğuna göre, anlamlandırmayı, değerlendirmeyi, çözümlemeyi, deneyimi ve yerleşmiş ilişkileri, "gündelik olan”ın dişında tutmak olanaklı olmayacaktır.

Literatürün hayatta kalma stratejilerine odaklanan bir diğer kolunu derinleşen yoksulluk karşısında kişilerin ve hanelerin verdikleri mücadelelere odaklanan çalışmalar oluşturmaktadır. Bu çalışmaların birleştiği nokta hayatta kalma stratejilerini, kıt kaynaklarla geçinme stratejileri olarak görmeleri ve bu stratejileri daha yapısalcı bir sorgulama ile ele almalarıdır. Bu yüzden bu alanda yapılmış birçok çalışmada, hayatta kalma stratejisi, hane halkı stratejisi, geçinme stratejisi, mücadele stratejisi kavramları sıklıkla benzer şeyleri ifade etmek için kullanılır ve kavramsal bir çeşitliliğe ve karmaşaya sebep olur. Hazırlanmış oluna bu çalışmada ise kapsayıcılığının daha fazla olduğu düşünülen hayatta kalma stratejisi kavramı tercih edilmiştir. Bu çalışmaların büyük bir çoğunluğu bu "stratejileri", yoksulluk, göç, kentleşme, enformelleşme gibi toplumsal sorunlarla ilişkilendirerek açıklar. Özellikle yoksulluk çalışmaları içinde hayatta kalma stratejileri oldukça önemli bir yere sahiptir. Bu çalışmalar içinde de Latin Amerika kökenli teorisyenlerin ağırlığı büyüktür. $\mathrm{Bu}$ teorisyenler, kendi ülkelerinin öznel deneyimlerinden yola çıkarak yoksullukla mücadele edebilme adına geliştirilen hayatta kalma stratejileri üzerine odaklanmaktadırlar. Philip Amis (1989), Filemon. C. Rodriguez (1992), Mercedes Gonzales de La rocha (1995), Edwin Melendez (1989), Henrique Cardosa (1977)'nın çalışmaları, literatürde önemli bir yere sahiptir. 
Türkiye'de de benzer eğilimler söz konusudur. Post yapısalcılık etkisinde gündelik hayat politikalarını kültür odaklı değerlendiren çalışmaların yanı sıra bu politikaları hayatta kalma stratejileri özelinde, yoksulluk, göç, ekonomik kriz gibi yapısal sorunlar üzerinden sorgulayan çalışmalar da bulunmaktadır. Ersoy ve Şengül (2008)'ün kentsel yoksulluk ve geçinme stratejileri üzerine yapmış oldukları çalışmaları, Boratav (1991) 'in farklı sınıfların geçinme stratejilerine yer verdiği çalışması, Şenses (2001)'in küreselleşme sürecinde yoksulluğun anlamını ve hanelerin hayatta kalma stratejilerini sorguladığı çalışması, Bora (2007)'nın yoksullaşma sürecinde hayatta kalma stratejilerini kadın emeği üzerinden sorguladığı çalışması, Erbaş ve Turan (2009)'in 2001 ekonomik krizinin farklı kesimler üzerindeki etkilerini sorguladığı çalışmaları, Türkdoğan ve Bayat $(1974,2008)$ 'ın yoksulluk kültürü içinde hayatta kalma stratejilerini sorguladıkları çalışmaları, Şahin (2013)'in işçilerin kullandıkları hayatta kalma stratejileri ile ilgili çalışması, Meder ve Şahin (2010) 2008 ekonomik krizinin farklı toplumsal sınıflar üzerine etkilerini sorguladıkları çalışmaları bu alanda önemli örneklerdir. Bu örnekleri sayısı oldukça fazladır ve literatüre katkıları büyüktür.

Türkiye'de hayatta kalma stratejilerine ait literatür, sosyo ekonomik bir takım değişimlere bağlı olarak değişime uğramıştır. 1990'lara kadar Türkiye'de hayatta kalma stratejileri, köyden kente göç üzerinden ele alınmıştır (Bora, 2007:98-99). Bu yıllar, Türkiye'de köyden kente göçün dalga dalga yaşandığı y1llardır. Göçle gelen ailelerin hem ekonomik hem de eğitim bakımından oldukça dezavantajlı konumda olmaları, geleneksel tutunma çabalarını ön plana çıkarmıştır. Hemşehrilik bağları, akraba ilişkileri, kentte hayatta kalmaya çalışan aileler için en önemli hayatta kalma stratejileri olmuştur. Göç eden kişiler, sahip oldukları sosyal sermaye aracılığıyla konut ve iş edinebilmişlerdir.

$\mathrm{Bu}$ dönem çalışmalarında hayatta kalma stratejiler tek, bütüncül ailenin ortak ürünü gibi görülmüştür. 1990'larla beraber haneyi bir bütün gören dolayısıyla da hayatta kalma stratejilerini bir bütünün ortak davranışı olarak değerlendiren çalışmalar yerini başka bakış açısına bırakmışlardır. Hayatta kalma stratejileri salt işbirliği ve dayanışmanın ürünü olmaktan ziyade çatışma alanları olarak görülmeye başlanmıştır. Hane içinde farklı bireylerin farklı stratejiler geliştirebileceği gündeme gelmiş ancak bu sefer de kadın emeği ve geleneksel bağlar ön plana çıkmıştır (Bora, 2007:98-99).

Göç etmiş ailelerde kadınların gündelikçi ya da başka enformel işler yapmaları önemli bir hayatta kalma stratejisi olmuştur. 1980-1990 y1lları arasında Ankara ve İstanbul'daki gecekondu semtlerinde kadınların çalışma oranı, \%8 oranında artış göstermiştir (Boratav, 1991: 115). Bu yılları takip eden 1990'lar ve 2000'lerde geleneksel bağların çözülmesi, enformel istihdam biçimlerinin daha da yaygınlık kazanması, kadın ve çocuk emeği üzerinden kurulan stratejilerin yerleşmesinde etkili olmuştur.

Bora (2007: 99)'a göre hayatta kalma stratejileri ile ilgili Türkiye'de yapılmış çalışmaların en büyük sınırlılığı, bu stratejileri geleneksel yapıların bir 
uzantısı olarak görme eğiliminde olup, kapitalizm boyutunun gözden kaçırılmasıdır. Bu tespit doğru olmakla birlikte hayatta kalma stratejilerini, enformel istihdam, kriz, yoksulluk gibi olgular üzerinden sorgulayan çalışmaların, bu sınırlılığı büyük ölçüde aşmaya çalıştıkları söylenebilir. $\mathrm{Bu}$ çalışmaların birçoğunda köyle kurulan bağlar, kentlerdeki hemşehrilik ve akraba dayanışmaları, hane içi yiyecek ve içecek üretimi, önemli hayatta kalma stratejileri olarak görülmeye devam etmektedir. Ancak bu çalışmaların büyük çoğunluğu, geliştirilen bu stratejileri, kapitalist üretim ilişkileri ve bu ilişkilerin içinde bulunduğu karışıklıktan doğan zorunluluklar çerçevesinde sorgulamaları bakımından önemli bir kırılma yaratmışlardır.

Türkiye'de özellikle 1990'ların sonu ve 2000'lerle beraber dayanışma odaklı geleneksel stratejilerin azaldığını ortaya koymaya çalışan eserler verilmiştir. Şentürk (2008), Bora (2007), Erder (1996)'ın çalışmaları bu çerçevede değerlendirebilir. 2000 sonrasında literatür ağırlıklı olarak yoksulluk çalışmaları üzerinden yapılanmaktadır. Özellikle yoksullukla mücadeleye odaklanan hane halkı stratejileri ve geçinme stratejileri adı altında birçok alan araştırması mevcuttur. $\mathrm{Bu}$ çalışmalar, yoksulluğun hanelerin ve kişilerin gündelik hayatlarını nasıl şekillendiğini ortaya koyması açısından oldukça önemlidir. Ancak yapısal çözümlemelerden uzak olmaları sebebiyle, yoksulluğun yapısal ve daha makro bir gerçeklik olduğunu gözden kaçırırlar.

\section{Hayatta Kalma Stratejisi Kavramı ve Kavram Üzerine İnşa Edilmiş Türkiye'deki Alan Araştırması Örnekleri}

Hayatta kalma stratejileri, yaşamak için gerekli olan tüm maddi ve manevi varlıklar ve aktiviteleri içine alır. Hayatta kalmak, doğal kaynakları tüketmeden, her tür stres ve beklenmedik olay ile başa çıkmak, sahip olunan mevcut varlıkları bugün ve gelecekte korumak, iyileştirmek ve sürdürebilmektir (Carney, 1998: 2). Kavramı bireysel veya hane odaklı ele alan tanımlar bulunmaktadır. Örneğin Tilly (1987), kavramı, haneyi bir bütün olarak etkileyen, hanenin günlük yaşam içinde karşılaştığı sorunları çözmeye hedefleyen girişimler olarak kabul eder. Boratav (1991: 112)'e göre ise konut mülkiyeti, dayanıklı tüketim mallarına dayalı belli bir yaşam standardını koruyabilme ve geliştirmek adına verilen tüm çabalar, hayatta kalma stratejisi olarak kabul edilebilir.

Genel olarak hayatta kalma stratejileri, tekil, parçalı, heterojen öğelerden oluşan bir idare etme sanatıdır. Bireylerin ve ailelerinin yaşamlarının temel ihtiyaçları olan barınma mekanı, kentsel kolektif tüketim, enformel işler, iş firsatları, kamusal mekan elde etmek için sessiz, gösterişsiz, kolektif olmayan ve uzun süreli doğrudan eylemlerdir. Kaçak elektrik kullanmadan, kadınların yemek ve beslenme ile ilgili her türlü yaratıcık biçimlerine, seyyar satıcılık ve işportacılık yapmaya kadar geniş bir yelpazeyi kapsar (Türdoğan, 1974; Bayat,2008 akt Erdoğan, 2007: 40).

Hane halkı stratejileri kavramının, belirli sınırlılıkları olduğunu düşünen teorisyenler de bulunmaktadir. $\mathrm{Bu}$ teorisyenler, kavrama dair temel 
sınırlılıklarını aşmak için geçim ve mücadele stratejileri ve "yoksulluğun kaynakları" gibi kavramlar ve yeni modeller geliştirmişlerdir. Gonzalez de la Rocha (2001), Robert (1991)'nın da için de bulunduğu bu grubun temel eleştiri noktaları, kavramın özellikle son yirmi yılda Latin Amerika gibi yoksulluğun derinleştiği ülkelerde yoksulluğu açıklamada yetersiz kaldığına inanmalarıdır. $\mathrm{Bu}$ teorisyenlere göre "gelir ve refah" işgücü piyasalarının da etkin rol oynadığı karmaşık süreçlerin sonucudur. Ayrıca yoksulların eylem kapasitesi, toplumların kalkınmayı ve sosyal hareketliliği doğrudan kolaylaştıran ve sınırlayan sosyal politikaların varlığına bağlıdır. Gonzalez de la Rocha (2001:73) bu konuda Meksika kentlerini örnek verir. Meksika'nın Guogolajara kentinde 1980'lerin başında düşük ücretlere rağmen, yoksulların nasıl hayatta kaldıklarını sorguladığı çalışması modelin ortaya çıkmasında belirleyici olmuştur. Meksika kentlerinde ekonomik koşullar ve işgücü piyasaları, orta sınıf hane halklarını önemli ölçüde etkilemiştir. Kentsel yoksul haneler, hayatlarını nasıl kazanacakları konusunda artık gerçek seçimler yapamayacak durumdadırlar. Özellikle yoksul haneler, düzenli gelir elde etme imkânını yitirmişlerdir. Düzenli bir maaş ile geçinme giderek yerini işportacılık, hane içi üretim, küçük meta üreticiliği gibi gelir sağlayıcı aktivitelere bırakmıştır. Bu durum aynı zamanda yoksulluların, sosyal hareketlilikte bulunacakları temel ağlara ulaşma kapasitelerini de doğrudan etkilemiştir. Robert (1995) gibi birçok teorisyen de Gonzalez de la Rocha'ın çalışması ve Latin Amerika örneğinden yola çıkarak "yoksulluğun kaynakları" modelini şekillendirmiştir. Bu model ile yoksulluğun hayatın tüm yönlerini nasıl etkilediğini ve ekonomik ve yapısal değişimin aileler, kadın ve erkeğin işleri üzerindeki etkilerini aydınlatmayı amaçlamışladır.

Engelen'e (2002:456-7) göre de strateji kavramı "bireyi” özgür, aktif ve her tür yapıdan bağımsız seçimler yapabilen aktörler gibi göstermektedir. Oysaki bireyin seçme özgürlüğüne sahip olmasına gereğinden fazla önem verilmektedir. Çünkü hiçbir birey ve dolayısıyla onun oluşturduğu hane, içinde bulunduğu sosyo ekonomik koşullardan bağımsız kararlar verebilecek koşullara sahip değildir. Bu yüzden Engelen'e göre strateji kavramı, mevcut olanlar içinden en akıllıca olanı seçmektir. Schmink (1984)'in strateji kavramı da Engelen de dâhil olmak üzere benzer çaba içerisinde olan teorisyenlerle aktörün akılcılığı ve sınırlı kaynaklar içinde de olsa seçim yapabilecek aktiflikte olduğu noktalarında paralellik gösterir. Schmink, kavramlaştırmasını başa çıkma stratejileri için yapsa da hayatta kalma stratejilerini de içine alacak bir kapsama sahiptir. Schmink (1984: 10)'e göre sosyo-ekonomik olarak yoksul olan hanelerin, yiyecek, giyecek, barınma gibi temel ihtiyaçlarını karşılamak, ekstra gelir elde etmek ve toplumsal refah seviyesinin çok altına düşmemek için kullandıkları tüm stratejik eylemlerdir. Başa çıkma stratejileri, alternatif eylem planlarının bilinçli bir değerlendirmesine dayanan stratejik eylemler dizisidir. Bazen sosyoekonomik olarak yoksul olan hane halkı, sınırlı seçenekler içinde kendine en faydalı eylem planını seçerler. Bu durum, mutlaka eylem planlarının, daima 
amacına hizmet edeceği anlamına gelmez. Öyle ki bazen bu stratejiler, sosyoekonomik konumları istemeden de olsa sadece devam ettirmeye yarar.

Delarrocha (1995: 15) hayatta kalma stratejilerini, hane içi ve dışı olmak üzere iki grupta toplar. Hane içi stratejiler, mal ve hizmet tüketimini sınırlandırmaya ve bunlara ilgili alternatifler bulmaya yöneliktir. Hane dışı, stratejiler ise aile üyelerinin daha fazla oranda ve sayıda işgücüne katılmalarını kapsar. Türkiye'de hayatta kalma stratejileri üzerine yapılmış çalışmalar üzerinden böylesi bir kategorizasyonu somutlaştırılabilir. Örneğin Güneş (2010:52-54)'in kadın emeği ve hayatta kalma stratejileri ile ilgili olan çalışmasında, yoksullukla mücadele edebilmek için kadınların da işgücüne katılmaya yönelmeleri, hane dişı stratejilere örnek gösterilebilir. Şahin (2013) çalışmasında kadınlar arasında ailenin geçimi sağlamak ve dışardan satın almamak için bazı temel gıda maddelerinin ev içinde üretildiğini gözlemlemiştir. Eskişehir'de 151 kadın ile yapmış olduğu çalışmanın sonuçlarına göre, çalışmaya katılan kadınların ekmek, mantı, tarhana-erişte, turşu , salça , konserve ve reçel yapmaktadır. Kadınların gelişmiş oldukları bu stratejiler hane içi stratejiler olarak değerlendirilebilir. Kaztman ve Filgueira (1999 akt Rosas, 2002: 84) ise stratejileri, k1sa dönem ve uzun dönem olacak şekilde kategorize etmektedir. Geçim stratejilerini, yoksullukla başa çıkmak için geliştirilen kısa dönemli stratejiler olarak kabul ederler. Buna karşın toplumsal hareketlilikle doğrudan ilgili olan ve insan sermayesi gerektiren toplumsal bütünleşme stratejileri de vardir.

Hayatta kalma stratejilerinin kavramsallaştırılması kadar, nasıl kategorileştirileceği de önemli bir sorunsaldır. Rakodi (1995:320), kendi ile benzeri çalışmaların bir sentezini yaparak, dört temel strateji grubu oluşturur. Bu kategorizayonu yapmak için öncelikli olarak bu stratejileri oluşturan temel sermaye çeşitlerini tanımlar.

Doğal sermaye: toprak, su ve diğer çevresel kaynaklardan oluşan doğrudan doğadan elde edilen doğal kaynaklardır. Özellikle kırsal yoksulların yaşamları, bu kaynaklara bağımlıdır. Genellikle özel mülkiyet olmadan bu kaynakları ortak bir şekilde kullanırlar. Kentsel yoksullar için de doğrudan ve dolaylı olarak gıda, enerji ve su temini için doğal kaynaklar oldukça önemlidir.

Fiziksel sermaye: üretim için gerekli olan tüm araç gereçlerdir. Kredi, emeklilik, tasarruf gibi finansal araçları da içerir. Rakodi’nin bu kavramı Marx'ın üretim araçları kavramı ile oldukça örtüşmektedir.

Sosyal sermaye: Bireylerin ve hanelerin amaçlarına ulaşmasını sağlayan her tür sosyal ilişkiler, sosyal yapılar, toplumun kurumsal yapısını oluşturan kurallar, normlar, yükümlülükler, karşılıklılık ve güven ilişkileridir. Bourdieu ile sosyal bilimler literatürü içinde oldukça etkin bir hale gelen kavram, özellikle Türkiye gibi geleneksel değerlerin hâkim olduğu toplumlardaki birçok mekanizmayı ve ilişki ağını açıklamada oldukça işlevseldir. 1950'ler ve 1980'lerde Türkiye'de büyük şehirlere doğru yaşanan göç dalgalarında, hemşehrilik bağları hem iş bulma hem barınmada etkin bir şekilde belirleyici 
olmuştur. Özellikle ilk kuşak gecekondulaşma süreci, bu çerçevede değerlendirebilir. Gecekondu, akrabalar ve hemşehrilerin şehre sonradan gelen akrabaları için bir gecede inşa ettikleri bir hayatta kalma stratejisi olarak kullanılmıştır.

Sonraları ranta dönecek gecekondular, bir araya gelerek aynı köyden kişilerin birlikte oturduğu mahalleleri oluşturmuştur. Suğur ve ark. (2008: 166)'ın gündelikçiler, kapıcılar ve çocuk bakıcıları üzerine yapmış oldukları çalışma, sosyal sermayenin özellikle kentli yoksul sınıflar için işgücünü dâhil olabilmede ne denli önemli olduğunu ortaya koyar: gündelikçilerin bakıcıların da önemli bir kısmı $(\% 35,5)$ işlerini arkadaşları aracılığıyla bulduklarını belirtmişlerdir. İş bulmaya aracılık etmede daha sonra komşular $(\% 23,5)$ ve akrabalar $(\% 22,5)$ önemli bir paya sahiptirler. Kapıcıların \% 36'sı arkadaşları vasıtasıyla, \%31'i kendisi iş arayarak, \%20'si akrabaları vasıtasıla, \%6's1 hemşehrileri vasıtasıyla, \%5'i kapıcı arkadaşlarının referansıyla ve \%2'si komşuları vasıtasıyla iş bulabilmiştir.

Rakodi (1995:320), insan sermayesini de hayatta kalma stratejilerinin son bileşeni olarak ele alır. İnsan sermayesi, hane içinde var olan emek kaynaklarının toplamıdır. Bir hane içinde kaç kişinin var olduğu, hanenin üretim ve yeniden üretimini doğrudan etkiler. Bu kişilerin eğitim düzeyleri ve sağlik durumları (üretebilirlik açısından) yoksullukla mücadeleyi etkiler. Türkiye'de özellikle kırsal alanda çocuk sayısının fazla olması, ücretsiz aile işçiliği olgusu, bu çerçevede değerlendirilebilir.

Rakodi (1995: 320)'nin sermayeler üzerine kurduğu ve diğer teorisyenlerden yararlanarak şekillendirdiği temel stratejiler:

1) Doğal, fiziksel veya insani sermayelerin yoğun bir şekilde kullanarak kaynakları arttırmaya yönelik stratejiler:

a) Hayvancılık ve kendi ürünlerini ekip biçmek gibi yöntemlerle kendi yiyecek üretimini arttırmak,

b) İşgücüne daha fazla hane halkının dâhil olması, evin odalarının kiralanması, göç ederek yeni istihdam yerleri bulmak

2) İnsan sermayesinin miktarını arttırmak,

a) Çocuk sahibi olmayı ertelemek ve durdurmak veya onları bakılmaları için başka yere göndermek (bu yollarla hane halkı büyüklüğünü azaltmak)

b) Hane halkını büyütmek, çocuk bakımı için ailenin yaşça büyük kadınlarını getirmek, çocukları evlendirerek haneye içinde çalışabilecek konumdakilerin sayısını arttırmak

3) Sosyal sermaye ilişkin stratejiler

a) Borçlanma, yardımlaşma, sadaka

4) Fiziksel, sosyal, doğal sermaye tüketimini sınırlamak ve azaltmak için kullanılan stratejiler

a) Yeni kıyafet, lüks yeme içime, tüketim kalıplarını azaltmak veya ortadan kaldırmak 
b) Günde pişmiş öğün sayısını azaltmak, daha düşük kaliteli veya daha az yiyecek satın almak

c) Ucuz veya ikinci el kıyafet almak

d) Çocukları okuldan almak

e) Tibbi tedavileri erteleme

f) Memleket ziyaretleri, komşuluk gibi tüm sosyal yaşam faaliyetlerini azaltma

g) Bazı varlıkları zorunlu bir şekilde satma

h) Yakıt veya atık toplama

Hayatta kalma stratejileri, Türkiye'de gündelik hayat içinde yoksulların ve daha birçok grubun sürekli olarak başvurdukları stratejilerdir. Bunlar bilinçli ve planlı olmaktan çok hayatın getirilerine bağlı olarak şekillenen, "öyle olması" gerektiği için yapılanan günlük olağan eylemlerdir. Çoğunlukla da bu stratejilerle yaşamak durumunda kalan aktörler, belirli bir seçim yaptıklarının farkında bile olmazlar. Örneğin hane gelirleri yetmeyen bir ailede annenin çalışmak durumunda kalması sonucunda aile büyüklerinin, yakın akrabaların veya komşuların çocuğa bakması oldukça olağan, sıklıkla başvurulan bir davranış şeklidir.

Türkiye'de hayatta kalmak adına maddi ve manevi anlamda tüketimi ve tüm giderleri kısmak alt ve orta sınıfin en sıklıkla başvurduğu stratejilerdir. Bu durum, ekonomik kriz gibi şok durumlarında çok daha belirginleşmektedir. Benzer şekilde özellikle kadın emeği üzerinden hane içi üretimi arttırarak bazı gider kalemlerine azaltmak da oldukça sıklıkla başvurulan stratejilerdir. Erbaş ve Turan (2009: 57)'ın, 2001 ekonomik krizinin farklı kesimler üzerindeki etkilerini sorgulayan çalışmanın sonuçlarına göre, çalışmaya katılanların \% 92,5'i ekonomik krizle başa çıkabilmek için daha az alışveriş yaptığını, \% 85'i ise daha ucuza alış veriş yaptığını, belirtmiştir. Az ve ucuza tüketmeye çalışmak, et, süt gibi ürünlerin ikamesini bulmak, Türkiye'de oldukça yaygın bir hayatta kalma stratejisidir. Hane içi yiyecek üretimi, kriz sonrasında $\% 47,5$ oranında artmıştır. Bu dönemlerde evde hamur işi yapmak, örgü örmek, sebze kurutmak, konserve yapmak gibi faaliyetler belirgin şekilde artmıştır (Erbaş, 2009:57). Benzer bir bulguya Şahin ve Meder (2010: 10-2)' in 2008 ekonomik krizinin Türkiye'deki farklı sınıflar üzerine etkilerini sorguladıkları çalışmalarında rastlanır. Katılımcıların yaklaşık \% 30'u hane içi üretim yaparak, ekonomik krizin etkilerini azaltmaya çalıştıklarını belirtmiştir. Özellikle hane içi giyecek ve yiyecek üretimi, kadın emeği üzerinden ilerlemektedir. Bu tarz stratejiler, kadınların, diğer kadınlardan öğrendikleri hayatta kalma stratejileridir. Şengül ve Ersoy (2000:92), Ankara ilindeki kentsel yoksulluk ve geçinme stratejileri üzerine yapmış oldukları çalışmalarında, tüketimden kısıtlama yapmanın, et gibi pahalı tüketim mallarını mümkün olduğunca almamanın ve ev içinde sadece kendi tüketimlerine yönelik gıda üretmenin, oldukça yaygın stratejiler olduğunu gözlemlemişlerdir. 
Işık ve Göktürk (2011: 314-315)'ün araştırması da bu stratejilerin Türkiye'de ne denli yaygın olduğunu desteklemektedir. Yoksulluğun azaltılmasına yönelik olarak ağırlıklı olarak kadınlar, hane içi etkin rol üstlenmektedirler. Kışlık ve yazlık gıdaların hazırlanması, ekmek gibi temel besin maddelerinin evde yapılması, eski eşyaların yeniden kullanılması ve sebze meyve yetiştirilmesi kadınların geliştirdikleri temel stratejilerdir. Ayrıca konserve yapmak, evde parça başı karşılığında düşük ücretlerle çoğunlukla el işi olmak üzere ev-işçiliği yapmak yoluyla hane-içi gelire katkıda bulunmaktadırlar. Yoksul kadınlar, hane bireylerinin giyim ihtiyaçlarını, dikiş dikerek ve örgü örerek karşılamaya çalışırlar (Işık ve Göktürk, 2011: 314-315). Hem gelir sağlama hem de besin elde etme amaçlı bir diğer faaliyet ise hayvansal üretimin hane içinde gerçekleştirilmesidir.

Parçalanmış ailelerin temel stratejilerini araştıran araştırmalarında Yusufuoğlu ve Kızmaz (2015: 14) süt, peynir, yoğurt gibi hayvansal ürünlerin bir strateji olarak hane içinde üretildiğini ve bu durumun daha çok kentin kenar mahallelerinde ve merkezden uzak yerlerinde gerçekleştiği sonucuna ulaşmışlardır. . Yumurta ise en yaygın üretilen hayvansal üründür. Çalışma ayrıca hanelerin geliştirdikleri stratejileri çok detaylı bir şekilde ortaya koymuştur. Çok mecbur kalınmadıkça elektrikli eşyaları kullanmamak, akşamları karanlıkta oturmak, banyo sobası kullanma ve tüm ailenin belli bir günde banyo yapması, kışın banyo yapılacak suyun sobada, yazın da güneşin önünde 1sitılması, öğün atlama ve ebeveynlerin kaliteli yiyecekleri çocuklarına bırakmaları, sobayı yakmama ve battaniyeye sarılarak oturmak, kullanım suyunu bile şehir çeşmelerinden temin etmek, birçok eşyayı komşu ile ortak kullanma, çocuklarla aynı odada kalmak ve onları tek yatakta yatırmak, yemeği kışın sobada, yazın ateşte pişirme, yiyecek maddeleri çöpten toplamak, bu stratejiler için de tüketimi azaltmak adına geliştirilen anlamlı örneklerdir (Yusufoğlu ve Kizmaz,2015:14).

Güneş (2010: 57)'in yoksullukla mücadelede kadın emeğini konu alan çalışması da geliştirilen stratejilerin ağırlıklı olarak tüketimi sınırlamak yönünde olduğunu ortaya koymaktadır. Çalışmanın sonuçlarına göre: kadınların çoğu elektrik $(\% 92,4)$ ve su kullanımında $(\% 78,7)$, ulaşım maliyetlerinin $(\% 97,3)$, telefonun kullanilmasi $(\% 97,7)$ ve evin isitilmasinda (\%97) kisintiya gitmektedir, Elektrikten kısıntı genelde şu stratejiler kullanılarak yapılmaktadır: Kadınlar genellikle çamaşırı ellerinde yıkamakta, evi temizlerken elektrikli süpürge yerine çalı süpürgesi kullanmaktadır. Sadece bir odanın ışı̆̆ı yakılmakta, televizyon 1şı̆̆ında oturulmaktadır. Kışın buzdolabı çalıştırılmaz. Su sobanın üzerinde ya da bahçede kovanın içinde güneş enerjisi ile 1sıtılmaktadır. Düşük voltaj lamba kullanılmakta, evde olan elektrikli ev aletleri çok az kullanmaktadır. Su kullanma ile ilgili stratejiler, kadınların su ihtiyaçlarını tulumbadan karşılaması, çamaşır makinesinin nadiren kullanılması, gereksiz yere su akıtmaması, bulaşıkları akıtma su yerine leğende durulaması şeklinde olmaktadır. Ayrıca kadınlar çoğu ulaşım giderlerinden tasarruf etmek için iş ve 
alışveriş için otobüs ve tramvaya binmek yerine yürümeyi tercih etmektir. Kadınların ısınmadan tasarruf etmek için kullandıkları stratejiler ise sadece bir odaya soba kurma, az miktarda odun, kömür yakma, soğuk gelen yerleri kapatma, çocukların olmadığı saatte sobayı yakmama, ucuz kömür kullanma, atık maddeler yakma, kömürün külünü sslatıp tekrar yakma, yakılan kömürün artıklarını süzüp tekrar ısınmak için kullanma, yakılacak madde yoksa yorganın altında oturma, aile bireylerinin kalın giysilerle (palto, kaban vb.) evde oturmas1 şeklinde gerçekleşmektedir.

Hane içi maliyetleri azaltmak adına ulaşım ile ilgili stratejilerde gelişillmektedir Büyük alışveriş merkezlerinin servislerinin kullanılmasıdır yeni yeni yaygınlaşan bir stratejidir. Birçok kişi bu yöntemle gideceği semte veya yakına ulaşabilmektedir. Diğer bir strateji ise belediyelerden alınan aylık veya günlük kart alıp, "90 dakika" gibi uygulamalarla maliyetleri aşağıya çekmektir (Şahin, 2014).

Özellikle kentlerde giderleri azaltma yönünde sıklıkla başvurulan bir strateji de aile ile birlikte yaşamaktır. Aile ile birlikte yaşayarak kira giderleri azaltılabilmektedir. Özellikle göçle kente gelmiş geniş aile olma özelliğini koruyan haneler için bir arada yaşamak, birlikte çalışmak gelirlerin tek elde toplanması önemli bir yoksullukla mücadele stratejisidir. Şahin (2013: 168) 'in araştırması göstermiştir ki ailelerin en büyük gider kalemini kira oluşturmaktadır. Bu yüzden, kira giderlerini azaltmak ya da tamamen ortadan kaldırmak için böylesi bir strateji izlemesi oldukça anlamlıdır. Aile ile birlikte yaşamak iki biçimde olabilmektedir. Birincisi, tüm giderler ortak olacak şekilde birlikte yaşanmaktadır. Böylece ailenin tüm fertlerinin her türlü geliri tek havuzda toplanmaktadır. Paranın idaresi ise evin en büyük erkeğine aittir. İkincisi ise ailenin var olan evine kat çıkmak şeklindedir. Bu biçimde ailenin diğer fertleri ile gelirler ayrı da olsa ögünler birlikte yenmekte, mutfak masrafları genellikle bölüşülmektedir. Böylece kira giderleri ve mutfak masrafları kısılabilmektedir. Bu tarz yaşam biçimine de hem köyde hem şehirde rastlanılmaktadır. Ancak şehir merkezinde yaşayanlar arasında biraz daha yaygındır (Şahin, 2013:168). Özellikle gecekondu mahallerinde öncelikli olarak tek katlı bir gecekondu inşa edip sonrasında göçle gelen ailenin diğer üyelerine kat çıkılması Türkiye'de oldukça yaygın bir stratejidir. Bu durum geçiş ailelerine özgü bir durum olarak değerlendirilebilir. Göçle gelmiş bu aileler bazen de aynı mahallede farklı evlerde oturur. Ancak beslenme genellikle birlikte gerçekleştirir. $\mathrm{Bu}$ durum hem gıda hem de enerji bakımından önemli oranda tasarruf sağlamaktadır.

Giderlerin azaltılmasının yanında haneye ek gelir getirici stratejiler de Türkiye'de sıklıkla başvurulan stratejilerdir. Ek iş yapmanın, haneye ek gelir getirmek adına önemli bir hayatta kalma stratejisi olduğu söylenebilir. Şengül ve Ersoy (2000: 79)' in çalışmasının sonuçlarına göre hane reislerinin, Ankara'da ek iş yapma oranı \% 2 iken bu oran 2000 yılında \% 11,7'e yükselmiştir. Bu 
işlerin \% 70'e yakınının düzensiz işler olması, enformel istihdam biçimlerinin, hayatta kalma stratejisi olarak giderek daha fazla kullanıldığını göstermektedir.

Şahin (2013: 171)'in Denizli'deki tekstil işçilerinin hayatta kalma stratejilerini ele aldığı çalışmasında ek iş yapmanın yoğun mesai ile çalışan işçiler arasında zor olduğunu buna karşın özellikle çocukların öngörülemeyen ihtiyaçları karşısında işçilerin zaman zaman ek iş yapmaya başvurdukları sonucuna ulaşmıştır. Bu noktada cinsiyete dayalı bir ayrım ortaya çıkmaktadır. Çocukların bakımı, yemek yapma, temizlik gibi geleneksel rolleri yerine getirmeden sorumlu görülen kadın işçiler ek işi ancak kendi evlerinde yapabilmektedir. $\mathrm{Bu}$ çerçevede erkek işçilerin ek iş yapmak istediklerinde sıklıkla ev dışındaki işleri kadın işçilerin ise ev içindeki işleri tercih ettikleri söylenebilir. Kadın işçiler, ek gelir için eve iş alma yöntemine de başvurmaktadır. Evde parça başı iş yaparak hem ekstra gelire sahip olmakta hem de evlerinde işlerine devam edebilmektedirler. Böylece çocuklarından da uzaklaşmadan ek gelir elde etmektedirler.

Rakodi'in sosyal sermaye ile ilgili olarak kategorize ettiği borçlanma, önemli bir hayatta kalma stratejisidir. Eskişehir İşçi Profili Araştırması'nın sonuçlarına göre ev, beyaz eşya, araba, çocukların eğitim masrafı gibi giderlerin büyük bir çoğunluğu ancak borçlanma yoluyla karşılanmaktadır. İşçilerin \% 66'sinın herhangi bir yere borcu bulunmaktadır (Altan ve ark., 2005: 108). Veresiye, borçlanarak, taksitle alışveriş yapmak ise başvurulan diğer stratejilerdir. Şahin (2013: 177) işçilerin borç ihtiyacı olduğunda sıklıkla yakın akrabalardan ve tanıdıklardan nakit ya da altın aldığı sonucuna ulaşmıştır. Talep edilen miktar ve geri ödenecek süre ile ilişkili olarak borçlanma genellikle altın şeklinde olmaktadır. Şentürk (2008: 95-103)'ün Balat ve Koca Mustafa Paşa semtlerinde yapmış olduğu çalışması ise tam tersi bulgulara sahiptir. Yoksulluk arttıkça akrabalar, hemşehriler ve komşular arası yardımlaşmanın, giderek azaldığını ortaya koymaktadır. Bu yardımlaşmaların yerini, muhtar ve siyasi partiler aracılığıyla ulaşılan erzak, odun-kömür, iş; yardım çadırları ve yeşil kart uygulamaları almaktadır. Bora (2007: 107-108)'ın çalışması da Türkiye'de akrabalar, hemşehriler arasında yardımlaşma azalırken yeşil kart ve diğer sosyal yardım uygulamalarının arttığını yönünde benzer veriler içermektedir. Benzer şekilde Erder (1996: 257)'in Ümraniye'deki çalışması da hemşehrilik ilişkilerinin, artık zor durumda olan aileler için bir hayatta kalma stratejisi olmadığı yönündedir.

1980'lerle beraber Türkiye'de köyün destekleyici kurum olma işlevi giderek azalmaktadır. Erzak ve diğer birçok konuda köyden gelen destek görece de olsa azalmıştır. Bu durumun birçok farklı nedeni bulunmaktadır. Köydeki toprakların giderek parçalanması sonucu üretilen ürünlerin azalması veya artık hiç üretilemez hale gelmesi, artan göçlerle birlikte ailenin diğer birçok üyesinin de kente göç etmesi, devletin neo liberal politikalar sonucunda tarım sektöründen desteğini çekmesi ile tarımsal üretimin azalması, özellikle artan yoksulluk ve ekonomik krizler karşında köye gitme sıklığının giderek 
seyrekleşmesi bu nedenler arasında sayılabilir. Boratav (1991: 107)’’n işçiler arasında kısal bağların önemli bir strateji olduğunu savunduğu çalışması sonrasında yapılan birçok çalışma köyün işlevinin giderek azaldığı yönündedir. Berber (2003)'in çalışmasının sonuçlarına göre işçilerin köyle kurdukları bağ maddi olmaktan ziyade manevidir. İşçilerin beşte ikisi köyden maddi destek almakta, \% 12'si hafta sonu tarla, bağ bahçe işi ile uğraşmaktadır. Eskişehir İşçi profili Araştırması'nın sonuçları da benzerlikler içermektedir. İşçilerin sadece \% 13,6'sının köyden gelir elde ettiği toprağı bulunmakta, \% 18'ine erzak desteği gelmektedir (Altan ve ark., 2005: 183). Ankara'daki kent yoksulları üzene yapılan çalışmanın sonuçları da köyden gelen desteğin hayatta kalma stratejisi olarak giderek daha az oranda kullanılabildiğini ortaya koymaktadır. Çalışmaya katılan ailelerin \% 14, 3'ü köyden erzak desteği almaktadır. \% 42'si köylerine yılda sadece bir kez gidebilmektedir (Şengül ve Ersoy, 2000: 186-190). Şahin'in çalışması köyle kurulan bağın bir hayatta kalma stratejisi olarak kullanılabileceğinin başka bir boyutuna dikkat çeker. Çalışmada

bakım çağında olan çocukların köylerine ya da ailelerinin yanına yollanmasının sıklıkla başvurulan bir strateji olduğu görülmüştür. Kreş ve bakıcı masraflarını ödemekde güçlük çeken işçiler, çocukların bakımını, birincil ilişkiler üzerinden yürütmektedir. Özellikle kadın işçiler, doğum sonrası izinleri bittikten sonra çocuklarını köye annelerinin yanına göndermekte ya da çok yakın akrabalarına şehirde baktırmaktadırlar. Çocukların köye gönderilmesi ile hem bakıcı masraflarından hem de çocukların bakılması için gerekli olan temel besin maddelerinden tasarruf edilebilmektedir. Çocukların süt, yumurta gibi ihtiyaçları köyde karşılanmaktadır (Şahin, 2013: 182). Şengül ve Ersoy (2000: 148 ) çalışmasının sonuçlarına göre çocukların kreş ve bakıcı masraflarının karşılanamaması durumlarında evde yalnız bırakılmaları da bir strateji olabilmektedir. Ailelerin \% 47,8'i maddi olanaksızlıklar sebebiyle çalıştıkları süre zarfında çocuklarını evde yalnız başına bırakmaktadırlar. Aynı çalışmaya katılan kadınların \% 33'ü çocuklarına bakacak kimseyi bulamadıkları gerekçesiyle çalışamadığını belirtmiştir.

Kişilerin sosyal alanlardan çekilmesi, sosyal yaşam faaliyetlerini sınırlandırılması başvurulan diğer stratejiler arasındadır. Birçok aile hanenin sadece temel ihtiyaçlarını karşılamaktadır. Komşu ve memleket ziyareti, tatile gitmek, sinemaya gitmek gibi birçok sosyal faaliyeti yapmaktan kaçınmaktadır. Şahin ve Meder (2010) 2008 yılında yaşanılan ekonomik kriz karşısında hanelerin geliştirildiği stratejileri sorguladıkları çalışmaları, bu durumun Türkiye'de mevcut olan geleneksel yapıyı ve ilişkilere zarar verdiğini göstermiştir. Katılımcıların birçoğu akraba ve yakınlarının düğünlerine bile gitmekten kaçındıklarını, dost ziyaretlerini bıraktıklarını belirtmişlerdir. Gerekçe olarak altın takmanın giderek maliyetli olduğundan, misafir ağılamak için gerekli olan mutfak masraflarını kısmak zorunda olduklarını anlatmışlardır.

Türkiye'de hayatta kalma stratejilerinin daha uç noktalarda yer alan örnekleri de bulunmaktadır. Dilencilik ve çocukların çalıştırılması bu anlamda 
en uçta kabul edilebilecek stratejilerdir. Kalfa-Topateş (2015), "Dilenciler, Türkiye'de Yoksulluk ve Dilenme Kültürü" adlı çalışmasında dilenciliğin, yoksullar için bir hayatta kalma stratejisi olduğu bulgusuna ulaşmıştır. $\mathrm{Bu}$ durumu, 1980 sonrası yaşanılan dönüşüme ve derinleşen yoksullukla ilişkilendirmiştir. Dilenciliğin boyutları ve dilenme kültürü ile daha derinlemesine bir analizin yapılması hazırlanmış olan bu çalışmanın boyutlarını aşmaktadır. Benzer bir durum çocuk işçiliği için de geçerlidir. Göçle büyük şehirlere gelmiş veya tarımda mevsimlik işçi olarak çalışan aileler için çocuk emeğinin gelir elde etmede bir araç olarak görülmektedir. Çocukların çalıştırılması bazen gönüllü bazen de zorunluluklar sonucunda bir hayatta kalma stratejisi olarak kullanılabilmektedir. Şişman (2003: 9-10)'a göre göç sonrasında kentte gelen birçok aile için çocuğun evde ya da tarlada ücretsiz aile işçisi olarak çalıştırılmasıyla, herhangi bir işyerinde ücret karşılığı çalıştırılması arasında herhangi bir fark yoktur. Hatta çalışma yaşamında ücretli olarak yer alması ailesine parasal katkı sağladığından çok daha tercih edilmektedir. Bu durumda kültürel bazı öğeler de etkilidir. Köyden gelen ailelerde kadınların çalışma yaşamında yer alması genellikle kabul edilemez olduğundan öncelikle baba ve erkek çocuklar çalışma hayatına girmekte, gereksinim duyulursa da kız çocuklar da çalıştırabilmektedir. Toplumsal bir sorun olarak çocuk işçiliğinin, bir takım formel nedenleri de bulunmaktadır. Öyle ki çocukların yaygın olarak istihdam edildikleri küçük işletmeler, tarım ve sokakta yürütülen işler ve ev hizmetlerinin İş Kanununun kapsamı dışında olması yanında, kapsamda olan işyerlerinin denetiminin etkin olarak yapılamaması, cezai müeyyidelerin yetersizliği mevzuat ve denetim alanındaki ciddi sorunlar, çocukların güvencesiz ve kötü koşullarda çalıştırılmalarının önünü açmaktadır (Avşar, vd., 2012:12). Tüm bu çalışmalar göstermektedir özellikle yoksullukla mücadelede çocuk işçiliği bir strateji olarak kullanılmaktadır. Özellikle Türkiye'de enformel sektörün genişlemesi ve denetimlerle ilgili boşluklar, hem ailelere hem de işverenlere bu açıdan açık alanlar oluşturmaktadır.

\section{SONUÇ}

1980'lerin sonuyla birlikte tüm dünyada hem ekonomik hem de ideolojik olarak yaşanılan dönüşüm sosyal bilimler literatürüne de yansımıştır. Çözülen kolektviteler karşısında bireyi temel alan yaklaşımlar, derinleşen yoksulluk ve diğer birçok toplumsal problemin çözümünde aktörü temel çıkış noktası olarak almışlardır. Uzun yıllar yapının üstünlüğü altında edilgenleştirilen edilen aktör, rasyonel seçimler yapabilen, bu seçimleri ile yapıyı da şekillendirebilen olarak gösterilmiştir. $\mathrm{Bu}$ durum, o döneme kadar aktörü çaresizliği ve edilgenliğine bir başkaldırı niteliğinde olmuştur. $\mathrm{Bu}$ durum, literatüre önemli açılımlar sağlasa da aynı zaman da belirli sınırlılıkları da beraberin de getirmiştir. Kuşkusuz ki en önemli sıkıntılardan biri, yoksulluk gibi toplumsal birçok problemin birey ve hane düzlemine indirgenmesidir. Bu durum, kolektif çözümlerin yerini bireysel mücadelenin alması sonucunu 
doğurmaktadır. $\mathrm{Bu}$ genel durumun arka planında hem teorik hem uygulama bazında birçok farklı alanı içine alan bir dönüşüm yatmaktadır.

Yoksulluğu hane ya da birey bazlı ele almak, toplumun belirleyiciliğini benimseyen holistik bakış açısının reddi, bunun yerine bireyi her türlü toplumsal olayın temel aktörü olarak gören bireyci/aksiyonel yaklaşımların kabulü olacaktır. Bu durum, post modernizm ve neo liberalizmin kollektiviteleri ikinci planda bırakan ve bireyi ön plana çıkaran söylemleri ile ideolojik ve kültürel olarak da desteklenmiştir. Hayatta kalma stratejilerinin yoksullukla mücadele stratejileri ile birlikte iç içe geçerek literatürde yerini almasının oluşturduğu bir diğer karışıklık, yoksulluğu stratejilerle çözümlenebilecek bir düzleme çekmesi, yoksulluğu bir idare etme sanatına dönüştürmesidir. Bu noktada Engelen'in eleştirisi de oldukça bütünleyici niteliktedir. Bireyler ancak ve ancak sınırlı olan seçenekler içinde en akıllıca olanı seçerler. Kuşkusuz ki bu seçimler yapının inşasına katkı sağlar. Tüm bu eleştirilere rağmen hane bazlı bir bakış açısı yoksulluğun doğrudan gözlemlenmesine olanak vermesi, yoksulluğun kişilerin gündelik hayattaki tezahürlerinin neler olduğunun anlaşılabilmesi açısından da önemli avantajlara sahiptir. Bu anlamda makro ve mikro olanın birleştirilmesi yönünde bir girişim, çok daha anlamlı ve işlevsel olacaktır. Bu noktada anlamlı olabilecek bir diğer nokta da kültürel olanın da analizlere dahil edilmesi olacaktır. Hem gelişme ve kalkınma yazının hem de yoksulluk ile ilgili teoriler temelde bu alanlara dahi temel problemleri genelleştirme eğilimi göstermektedir. $\mathrm{Bu}$ durum Türkiye de dahil olmak üzere birçok ülkenin özgül koşullarının analizlere dahil edilmesini zorlaştırmaktadır. Bu açıdan hem yoksulluk hem de yoksullukla başa çıkma stratejileri Türkiye'nin kedi özgül koşulları analize dahil edilemeden tam olarak anlaşılmayacaktır. $\mathrm{Bu}$ durum, toplumsal bir problem olarak olgulara yaklaşım biçimini bile doğrudan etkileyecektir. Örneğin Türkiye'de dinin ve tevekkül kültürünün etkisi, yoksulluğu bir problem olarak görme durumunu bile etkilemektedir. Benzer şekilde kendi haline şükretme kültürü içinde her tür isyan kabul görmemektedir. Bu durum, Türkiye içinde güçlü kolektif hareketlerin oraya çıkmamasında da belirleyicidir. Başka bir açıdan bakıldığında özellikle Türkiye gibi geleneksel ve modern birçok değerin bir arada olduğu ülkelerin anlaşılmasında kültürel çözümlemeler tamamlayıcı ve yol gösterici olacaktır. Öyle ki bir taraftan küreselleşme ve neo liberalizm etkisiyle dünya pazarları ile birleşen Türkiye'de özellikle hane odaklı stratejilerin temel aktörü olan kadının işgücü piyasalarına dâhil olması önünde hala geleneksel engeller bulunmaktadır. Hane dışında çalışmasına izin verilmeyen birçok kadın, yoksullukla mücadele edebilmek için kendi hanesinde parça başı iş yapmaktadır. Aynı mahallede yaşayan bir aracı kadın yardımıyla kurulan bu bağlar yardımıyla ek gelir elde eden kadınlar çoğunlukla güvencesiz ve düzensiz bir sistemin parçası haline gelmektedirler Çoğunlukla kimin adına çalıştığını bilme şansları bile bulunmamaktadır. Aynı şekilde hane dışına çıkması aile tarafında uygun görülmeyen ve çoğunlukla eğitim seviyesi düşük olan kadınlar için kendi evinde çocuk bakmak, veya bir tanıdığının referansı ile 
gündeliğe gitmek önemli stratejileridir. Türkiye'yi bu noktada özgün kılan nokta geleneksel ve modern olanın bu kesişim durumunun kendi içindeki handikapları, kadın istihdamını bir çeşit hayatta kalma stratejisine dönüştürmesidir. $\mathrm{Bu}$ durum, kadınları düzenli gelir, emeklilik gibi birçok temel haktan yoksun birakmaktadir.

Tüm bu tartışmalar 1şığında hayatta kalma stratejileri kavramının kendi içinde birçok avantajı ve dezavantajı bulunmaktadır. Öncelikli olarak kavram, Türkiye'de dâhil olmak üzere birçok gelişmekte olan ülke ekonomisinin yapısal uyum süreçleri ve neo liberal politikalardan nasıl etkilendiğini hane bazında anlama konusunda yardımcı olmuştur. Bireysel ve hanesel stratejilere odaklanarak bireyi pasifize edilmiş konumundan kurtarmıştır. Ancak aynı durum bazen dezavantajlara da yol açmaktadır. Aktif seçimler de yapsa bu seçimler sınırsız özgür bir alanda gerçekleşmez. Aktörler ancak ve ancak onlara sunulan sinırlılıklar içinden en akıllıca ve haneleri için en uygun olanı seçebilirler. Bu yüzden yoksullukla gibi toplumsal problemlerin yapısal çözümler olmadan anlaşılması imkânsızdır. Makrodan mikroya doğru katmanlı bir bakış açısı ve yapısal çözümleme bu stratejileri anlamlı kılacaktır. Örneğin hane bazında geliştirilen bir stratejiyi anlamak için öncelikli olarak dünyadaki ekonomik gelişmeler ve bu gelişmelerin ülke ekonomileri üzerindeki etkileri incelenmelidir. $\mathrm{Bu}$ etkilerin yerel pazarları ve işgücü piyasalarını nasıl dönüştürdüğü çözümlendikten sonra kişilerin ve hanelerin var olma süreçlerine kültürel farklılıkları da katarak bakılabilir. Böylece anlamsal bir bütünlük sağlanmış olunur ve yapısal farklılıklar gözden kaçırılmaz.

\section{KAYNAKÇA}

Altan, Z., Kağnıcıoğlu,D., Şişman, Y., Sungur, Z., (2005), İşçi Profili Araştırması: Eskişehir Örneği, Eskişehir: Anadolu Üniversitesi Bilimsel Araştırma Projeleri.

Amis, P., (1997), "Indian Urban Poverty, Where are the Levers of its Effective Aleviation", Institute of Development Studies Bultein, C.28, S.2, s.94-104.

Avşar, Z, (2012) "Çocuk İşçiliği ve Çocuk İşçiliği ile Mücadele Stratejileri” Sosyal Güvenlik Dergisi, 2012/1, ss.9-40.

Bayat, A. (2008) Sokak Siyaseti ,İran'da Yoksul Halk Hareketi, Phoneix Yayınevi

Berber, Ö., (2005), Toplumsal İlişkiler Bağlamında Sınıf Bilinci ve Sınıf Kültürü Seydişehir Eti Alimunyum Fabrikası Örneği, Yayınlanmamış Yüksel Lisans Tezi, Ankara: T.C Ankara

Üniversitesi Sosyal Bilimler Enstitüsü, Kamu Yönetimi ve Siyaset Bilimi Anabilim Dalı.

Bora, A., (2007), "Kadınlar ve Hane: Olmayanın Nesini İdare Edeceksin”, Yoksulluk Halleri: Türkiye'de Kent Yoksulluğunun Toplumsal Görünümleri, der. N.Erdoğan, İstanbul: İletişim Yayınları.

Boratav, K., (1991), 1980'li Yıllarda Türkiye'de Sosyal Sınıflar ve Bölüşüm, İstanbul: Gerçek Yayınevi.

Carney, D. (1998) 'Implementing the Sustainable Rural Livelihoods Approach'.Paper presented at DFID Natural Resource Advisers Conference, 5-9 July.

Cardoso, Fernando Henrique (1977), The Consumption of Dependency Theory in the United States, in: Latin American Research Review, 12, 3, 7-24.

Crow, G. (1989) 'The Use of the Concept of "Strategy" in Recent SociologicalLiterature', Sociology 23: 1-24

De Certeau, M. (2009). Gündelik hayatın keşfi I. L. A. Özcan (Çev.). Ankara: Dost Yayınları. 
Erbaş, H,, Turan, F., (2009), "2001 Ekonomik Krizinin Tüketim, Eğitim ve Sağlık Alanlarında Ücretli ve Esnaf Kesimlerine Yansıması", Gazi Üniversitesi Ekonomik Yaklaşım Dergisi, C. 15. S.50, ss. 47-67.

Engelen, T. (2002), "Labour Strategies of Families: A Critical Assessment of An Apppealing Concept", International Review of Social. History, 47: 453-464

Erder, S., (1996), Ümraniye: İstanbul'a Bir Kent Kondu, İstanbul: İletişim Yayınları.

Erdoğan, N., (2007), “Garibanların Dünyası: Türkiye'de Yoksulların Kültürel Temsilleri Üzerine İlk Notlar", Yoksulluk Halleri: Türkiye'de KentYoksulluğunun Toplumsal Görünümleri, der. N.Erdoğan, İstanbul: İletişim Yayınları.

Gershuny, J.I ve Pahl, R.E (1979) Workoutside employment: Some preliminary spucalations, New Universities Quarterly 34:1, 120-35.

Giddens, A. (1984), The Constitution of Society. Cambridge: Polity Press.

Gonzalez de la Rocha, M. (2001), "From the Resources of Poverty to the Poverty of Resources? The Erosion of a Survival Model", Latin American Perspectives, 28 (4):72-100

Güneş, Fatime (2010) Yoksullukla Başa Çıkma Statejileri, Kaynakların Yoksulluğu, Kadın Emeği, Folklor, Edebiyat, Cilt 16, say1 64: 33-64

Lefebvre, H. (2010). Modern Dünyada Gündelik Hayat. (I. Gürbüz, Çev.) İstanbul: Metis Yayınları Long, N. (2001), Development Sociology: Actor Perspectives. London:Routledge.

Işık, E. ve Göktürk, I (2011), "Kadınların Yoksulluk Yönetim Stratejileri” Uluslararası Yoksullukla Mücadele Stratejileri Sempozyumu-2, İstanbul: T.C. Başbakanlık SYDV, s.311-316

Meléndez, E. (1989), “Towards a Good Job Strategy for Latino Workers," Journal of Hispanic Policy 4.

Morgan, D.H.J. (1989) 'Strategies and Sociologists: A Comment on Crow',Sociology 22: 25-9.

Morris, L. (1997) 'Economic Change and Domestic Life', in R.K. Brown (ed.) Changing Shape of Work, pp. 125-49. London: Macmillan.

Moser, C.O.N. (1998) 'The Asset Vulnerability Framework: Reassessing UrbanPoverty Reduction Strategies', World Development 26 (1): 1-19.

Mueller, E.J. (1994) 'Running Hard to Stay in One Place: Low-wage Poverty among Immigrant Women in Los Angeles', Economic Development Quarterly 8(2):158-70.

Pahl, R.E. and Wallace, C. (1985) 'Household Work Strategies in an Economic Recession', in N. Redclift and E. Mingione (eds) Beyond Employment. Household, Gender and Subsistence. Oxford: Blackwell.

Pahl, R.E. (1988) 'Some Remarks on Informal Work, Social Polarization and the Social Structure', International Journal of Urban and Regional Research 12(2): 247-67.

Piirainen, T. (1997) Towards a New Social Order in Russia: Transforming Structures and Everyday Life. Aldershot: Dartmouth.

Pile, S. (1991) 'Securing the Future: "Survival Strategies" amongst Somerset Dairy Farmers', Sociology 25: 55-74.

Portes, A. (1994) 'The Informal Economy and its Paradoxes', N.J. Smelser and R. Swedberg (eds) The Handbook of Economic Sociology. Princeton, NJ: Princeton University Press.

Rakodi, C. (1995) 'Poverty Lines or Household Strategies? A Review ofConceptual Issues in the Study of Urban Poverty', Habitat International 19(4): 407-26.

Redclift, M. (1986) 'Survival Strategies in Rural Europe: Continuity and Change', Sociologia Ruralis XXVI: $15-27$.

Roberts, B. (1991) 'Household Coping Strategies and Urban PoverComparative Perspective', in M. Gottdiener and C.G. Pickvance (eds) Life in Transition. London: Sage.135:67

Rodriguez, H. 1992. Household composition, employment patterns, and income inequality: Puerto Ricans in New York and other areas of the U.S. mainland. Hispanic Journal of Behavioral Sciences 14:52-75.

Rosas, R.E. (2002), "Women and Survival Strategies in Poor Urban Contexts: A Case Study from Guadalajara, Mexico", JDSI, 18 (2-3):81-108

Rose, R. and Haerpfer, C.W. (1992) Between State and Market (Studies in Public Policy No. 204). Strathclyde: Centre for the Study of Public Policy. 
Schmink, M. (1984), Household economic strategies: review andresearch agenda. Latin American Review 19(3):87-101

Sewell, W.H. (1992), 'A theory of structure: duality, agency and transformation', American Journal of Sociology, 98(1): 1-29.

Suğur, N., S. Suğur ve T. Gönç-Şavran (2008), Türkiye'de Orta Sınıfın Mazbut Hizmetkârları: Kapıcılar, Gündelikçiler ve Çocuk Bakıcıları, Ankara Üniversitesi Siyasal Bilgiler Fakültesi Dergisi, 63 (3): 162-83

Şahin, Ö., Balta, E., (2001), “Gündelik Yaşamı Dönüştürmek ve Marksist Düşünce”, Praksis, Güz, $: 185-217$.

Meder, M., ve Şahin, M. (2010), "The Socio- Economic Effects of the 2008 Crisis on the different classes in Turkey", İsveç: 17. Dünya Sosyoloji Kongresi.

Şahin, H. (2013) Küreselleşme Sürecinde İşçilerin Direnme ve Hayatta Kalma Stratejileri, Bursa: Ekin Kitapevi.

Şahin, H .(2014) Urban Fenomenon As A Domain Of Resıstance Withın The FrameWork Of The Fight Against Powerty, Cities in Globalizing World, St. Klıment Ohrıdskı Unıversity Press

Şengül, T., Ersoy, M., (2000), "Kentsel Yoksulluk ve Geçinme Stratejileri: Anakara Örneği”, Ankara: ODTU Kentsel Politika Planlaması ve Yerel Yönetimler Anabilim Dalı 1999 YILI Stüdyo Çalışması.

Şenses, Fikret (2001): Küreselleşmenin Öteki Yüzü Yoksulluk, İletişim Yayınları, İstanbul.

Şentürk, M., (2008), Yoksulların Yaşam Stratejileri: Küçük Mustafa Paşa ve Balat Örnekleri, Sosyoloji Anabilim dalı yayınlanmamış yüksek lisans tezi, İstanbul: T.C İstanbul Üniversitesi Sosyal Bilimler Enstitüsü.

Şişman, Y (2003) “Sosyal Politika Açısından Türkiye'de Çocuk ve Genç İşgücü” Kamu-İş Dergisi, $\mathrm{C}: 7, \mathrm{~S}: 2, \mathrm{ss}: 2-34$.

Tilly, L.A. (1987), "Beyond Family Strategies, What?", Historical and Interdisciplinary History, 20 (3): $123-125$.

Topateş-Kalfa, A. (2015) Dilenciler, Türkiye'de Yoksulluk ve Dilenme Kültürü, Ankara: İletişim Yayınları

Türkdoğan, Orhan, (1974), Yoksulluk Kültürü, Atatürk Üniversitesi, Yayınları, No:336, Erzurum

Wallace, C. (2002), "Household Strategies: Their Conceptual Relevance and Analytical Scope in Social Research", Sociolo gy, 36 (2): 275-292

Yusufoğlu, Ö. Ş, Kızmaz, Z., (2015) Parçalanmış Yoksul Ailelerin Geçinme Stratejileri: Elazı̆̆ Örneği, Fırat Üniversitesi Harput Araştırmaları Dergisi Cilt: II, Sayı:2, 1-18 